\title{
Beyaz ve kahverengi ticari yumurtacı tavuklarda, tavuk yaşı ve kafes katının yumurta dış kalite parametreleri üzerine etkileri*
}

\author{
Bayram AKKUŞ1, İskender YILDIRIM² \\ ${ }^{1}$ Niğde İl Gıda Tarım ve Hayvancllık Müdürlüğü 51100 NĭĞDE \\ ${ }^{2}$ Selçuk Üniversitesi, Ziraat Fakültesi, Zootekni Bölümü, Selçuklu, KONYA
}

*Bu çalışma Bayram Akkuş'un Yüksek Lisans Tezi Özetinin yumurta dış kalite parametreleri üzerine olan kısmının özeti olup Selçuk Üniversitesi BAP Koordinatörlüğü tarafından 15201058 nolu projesi ile desteklenmiştir.

Alınış tarihi: 28 Şubat 2018, Kabul tarihi: 21 Mayıs 2018

Sorumlu yazar: İskender YILDIRIM, e-posta:iyildir@selcuk.edu.tr

\section{Öz}

$\mathrm{Bu}$ çalışmanın amacl, değişik yaş gruplarında ve farklı kafes katlarında yetiștirilen beyaz ve kahverengi yumurta tavuklarından elde edilen yumurtaların diş kalite özelliklerinin belirlenmesi/karşılaştırılmasıdır. Çalışmalarda ticari yumurtacı Nick-Chick ve Nick- Brown hibritlerinde farklı kafes katlarında $(1,3,5$. katlarda) 28, 52 ve 70 haftalık yaşlarda elde edilen yumurtaların dış kalite özellikleri arasındaki farklılıklar incelenmiştir. Dış kalite kriterleri olarak, yumurta ağırlığı, özgül ağırlık, şekil indeksi, kabuk kalınlığı, kabuk kırılma mukavemeti ve yumurta kabuk yüzey alanı değerleri belirlenmiștir. Sonuçta, tavuklarda genotip, yaş ve kafes katının yumurta ağırlığı, özgül ağırlık ve kabuk özelliklerine önemli etkileri bulunmuştur $(\mathrm{P}<0,01)$. Kafes katlarının yumurta kalitesine etkileri, birinci katın yumurta ağırlığı, şekil indeksi, kabuk kalınlığı, kabuk yüzey alanı, parametreleri bakımından diğer katlara (3-5) göre daha yüksek olarak tespit edilmiştir $(\mathrm{P}<0.01)$. Yumurta tavuklarında yaş ilerledikçe yumurta ağırlığının ve özgül ağırlığın arttı̆̆ı tespit edilmiștir.

Anahtar kelimeler: Genotip, kafes katı, yaş, yumurta kalitesi, yumurta tavuğu

The effect of hen age and cage floor on external egg quality traits of white and brown laying hens

\footnotetext{
Abstract

The purpose of the study is to investigate the effects of white and brown laying hens in various age groups and in different cage floors on egg external
}

quality parameters. In the study, the eggs obtained from commercial white Nick Chick and Nick Brown laying hens raised different floors of the chicken cages $(1,3,5$ floors), and 28,52 and 70 weeks of age. The project was carried out between 2015 and 2016 years. In order to determine the external quality characteristics of the eggs, the egg weight, specific gravity, shape index, shell thickness, breaking strength and egg shell surface area values were determined. As result, genotype, age and cage floor have a significant effect on egg weight, specific gravity and shell properties $(P<0.01)$. The eggs obtained from Nick brown genotype were heavier and had a higher specific gravity than that of white eggs. Regarding the effects of cage floors on egg quality parameters, the egg weight, shape index, shell thickness, shell surface area parameters were higher in the first floor than that of the other floors (3-5) $(\mathrm{P}<$ 0.01 ). As conclusion, the egg weight and egg specific gravity increases whereas the shell thickness values decreases with aging of the birds.

Key words: Age, cage floor, egg quality, Genotype, laying hen

\section{Giriş}

Yumurta insan beslenmesinde kritik besin maddelerinden birisidir. Özellikle bir dönem yumurtanın kalp damar hastalıklarını tetikleyici ve hatta önemli sebeplerden biri olarak tanıtılması, haksız ve yanlış görüş bildirimleri, tüketimi olumsuz etkilemiştir. Zararın neresinden dönülürse kardır mantığı ile son yıllarda bu yaklaşım tersine dönerek gerek tüketim gerekse üretim de artışlar olmaya başlamıştır. Tür- 
kiye kümes hayvan varlığı yıllar itibariyle önemli derecede artış göstermiş olup; 2005 yılında 60,3 milyon olan ticari yumurta tavuğu sayısı 2015 yılında 98,6 milyon âdete ulaşmıştır (TÜİK, 2016). Bilindiği gibi ülkemiz Damızlık teminini önemli seviyede uluslararası firmalardan tedarik etmektedir. Bu durum, gerek üreticilere gerekse bilim insanlarına elimizdeki genotiplerden verimli ve maksimum seviyede yararlanmayı şart koşmaktadır. Her kayıp ülke finans dengesine olumsuz yansıyacaktır. Dolayısıyla, verimi azaltan ya da negatif etkileyen her parametre tespit edilerek muhtemel kaçakları yok etmek kritik bir görev olarak değerlendirilmelidir. Yumurta kalitesi tüketici tercihleri kadar başarılı bir finansal kazanç için üretici açısından da önemlidir. Toplama, muhafaza, yükleme ve nakliye kadar kümesteki üretim şartları da kaliteyi belirleyen faktörlerden birisidir. Jacob ve ark. (1998), yumurta kabuk kalitesinde temizlik, şekil indeksi, kabuk yapısı ve sağlamlığının önemli olduğunu, bu özelliklerde kalıtım, hastalıklar, tavuğun yaşı, sıcaklık, besleme, yetiştirme şartları, stres gibi faktörlerin etkili olduğunu belirtmişlerdir. Siegel (2001), yumurta kalite parametrelerinin kalıtım derecesinin hesaplanmasında yumurtlama periyodunun uzunluğuna ve bu ilgili sürecin tekrar başlaması durumuna göre farklılık gösterebileceğini. Siegel (2004), Yumurta kalite kriterlerinin dinamik bir yapıda iç ve dış faktörlerden oluştuğunu, yumurta kalitesi diğer verim parametrelerinde olduğu gibi genotip ve çevre faktörlerince kontrol edildiğini ifade etmiştir. Örneğin, bazı kalite unsurlarının çok düşük bir genetik varyasyona sahipken, yumurta büyüklüğünde olduğu gibi çeşitli özelliklerin önemli seviyede genotipik varyasyon gösterdiğini rapor etmiştir. Laxmi et al. (2001), beyaz Leghornlarda (farklı hatlarda) yumurta kalite parametrelerinin tespitine yönelik yürüttükleri çalışmada, sarı özellikleri hariç diğer kalite parametrelerinin birbirinden farklı olduğunu tespit etmişlerdir. Bu hatlarda, seleksiyonla yumurta kalite üzerinde ilerlemeler yapılabileceğini bildirmişlerdir. Laxmi et al. (2002), Beyaz Legornlarda yürüttükleri çalışmada, şekil indeksini geliştirmeye yönelik çalışmalarında, bu parametre yanında aynı anda kabuk kalınlığı ve sarı oranında da artış sağlanabileceğini tespit etmişlerdir. Suk (2002), Hy-Line W-98 (WSL) beyaz yumurtacı ve Hy-Line Brown (BSL) sürülerinde yaptıkları çalışmada, Hy-Line Brown'ların yumurta verimi ve kabuk kalınlığının daha yüksek olduğunu, fakat daha düşük sarı oranına sahip olduğunu, yer tavukçuluğu üretiminde Hy- Line Brown'ların tercih edilmesi gerektiğini bildirmişlerdir. Durmuş (2006), yerli beyaz yu- murtacı saf hatlar ve hibritlerde yürüttüğü çalışmasında; yumurta kalite ve verim parametreleri bakımından kırılma direnci ve kabuk kalınlığı haricinde önemli bir farklılığın bulunmadığını bildirmiştir. Sarıca ve ark. (2010), yerli ve uluslararası menşeilihibritlerde yumurta kalitesinin yaşa bağlı değișimi konusunda yaptı̆̆ çalışmada, yerli genotiplerin kabuk kırılma direnci, kabuk rengi ve kısmen yumurta ağırlığı bakımından ıslah edilmesi gerektiği sonucuna varıldığını bildirmişlerdir. Singh (2009), LW, LB, HN, melezleri ile yumurta kalitesi yapmış olduğu çalışmada yumurta ağırlıklarının sıra ile 55,8, 56,6, $55,0,59,3 \mathrm{~g}$, yumurta akı yükseklikleri 8.66, 8.36, 8.57, $8.46 \mathrm{~mm}$, sarı rengi 5.41, 5.70, 5.26, 6.15 olarak belirlenmiştir. Brah et al. (1998), yaşları 28-30 ve 38-40 haftalık beyaz leghornlarda yürüttükleri çalışmada yaş artışına bağlı olarak özgül ağırlığın düştüğünü șekil indeksinin ise değişmediğini bildirmişlerdir. Kafes katlarının yumurta dıș kalite kriterlerine etkisi ile ilgili çalıșmalar (Yıldırım ve ark., (2008); Yıldız ve ark., (2006); Onbaşılar ve ark. (2005); Şekeroğlu ve ark., (2014); Karaman ve ark., (2013)) mevcut olmasına rağmen araştırmalardan elde edilen sonuçlarda farklılıklar mevcuttur.

\section{Materyal ve Yöntem}

\section{Materyal}

Bu araştırma; 2015-2016 yıllarında, Niğde İlinde 300.000 adet yumurta/gün kapasiteli, geleneksel kafes sisteminde yumurta üretimi yapan bir tavukçuluk işletmesinde yürütülmüştür. Kümes 12x60 m ebatlarında olup toplamda $720 \mathrm{~m}^{2}$ taban alanına sahiptir. Kümeslerde otomatik yemleme, sulama ve havalandırma sistemleri mevcuttur. Kümes içerisindeki kafesler 3 m yüksekliğinde 5 katlı ve 5 bloktan oluşmaktadır. Kafes gözleri 60x60 cm ebatlarında olup her gözde 9 adet olmak üzere toplam 35.000 adet yumurtacı tavuk yetiştirilmektedir. Çalışma konusu için seçilen yumurta tavuğu işletmesinde 4 ve 5 nolu kümeslerde çalışma yürütülmüștür. 5 nolu kümeslerde Nick Chick ve 4 nolu kümeslerde Nick Brown hibritleri yetiştirilmektedir. Kümeslerde 5 katlı geleneksel kafes kullanılmakta ve tünel tipi havalandırma yapılmaktadır. Kümeslerin fan kapasiteleri $37.000 \mathrm{~m}^{3} / \mathrm{dk}$.' dır. Kümeslerde yapılan ölçümlerde sıcaklığın ve ışık şiddetinin hem bloklar arasında hem de katlar arasında farklılı gösterdiği anlaşılmıştır. İki ayrı kümeste kümesin orta bloklar esas alınarak 4 ve 5 nolu kümeste yapılan ısıya duyarlı termometre ile ışılk Şiddeti yönünden lüksmetre ile 4 nolu ve 5 nolu kümeslerde orta blokta yapılan ölçümler aşağıdaki Çizelge 1'de verilmiştir. 
Çizelge 1.Kümeste katlar arası sıcaklık $\left({ }^{\circ} \mathrm{C}\right)$ ve ışık şiddeti (lüx) değerleri

\begin{tabular}{ccccccc}
\hline & 1.Kat & 2.kat & 3.kat & 4.kat & 5.kat & $\mathrm{X}_{\text {kümes ort. }}$ \\
\hline \multicolumn{5}{c}{${ }^{\circ} \mathrm{C} /$ Lux } \\
$\begin{array}{c}\text { Nick } \\
\text { Brown }\end{array}$ & $30.2 / 6$ & $32 / 8$ & $30 / 14$ & $30.2 / 18$ & $30.6 / 29$ & $30.6 / 15$ \\
\hline $\begin{array}{c}\text { Nick } \\
\text { Chick }\end{array}$ & $31.2 / 7$ & $33.2 / 8$ & $29.6 / 10$ & $29.8 / 16$ & $30 / 29$ & $30.8 / 14$ \\
\hline
\end{tabular}

Kümeslerde ışıı şiddetinin 6-29 lüx ışık şiddeti olduğu tespit edilmiștir. İki hibritin bakım kılavuzunda yumurta verim döneminde ortalama işık şiddetinin 10 lüx olması tavsiye edilmektedir. Her genotip için her kattan 4 tavuk olmak üzere toplam 20 tavuk tartılmıştır. Kümeste katlar arası canlı ağırlık (g) sonuçları Çizelge 2 verilmiştir.

Çizelge 2: Kümeste katlar arası canlı ağırlık değerleri (g)

\begin{tabular}{ccccccc}
\hline & 1.Kat & 2.kat & 3.kat & 4.kat & 5.kat & X kümes ort. \\
\hline $\begin{array}{c}\text { Nick } \\
\text { Brown }\end{array}$ & 1575 & 1435 & 1520 & 1655 & 1615 & 1560 \\
\hline $\begin{array}{c}\text { Nick } \\
\text { Chick }\end{array}$ & 2115 & 1805 & 1900 & 1860 & 1730 & 1882 \\
\hline $\bar{X}_{\text {kat }}$ & 1845 & 1620 & 1710 & 1758 & 1673 & 1722 \\
\hline
\end{tabular}

\section{Deneme planı}

Deneme materyali olarak aynı tip kafeslerde yetiștirilen beyaz yumurtacı Nick-Chick ve kahverengi yumurtacı Nick- Brown hibritlerinden elde edilen yumurtalar kullanılmıştır. Her iki genotipin belirtilen yaş aralığında iç ve diş yumurta kalitesi tespit edilmiştir. Yaş olarak pik verim dönemi olan 28. haftada içerisinde bir gün ilk yumurta kalite analizleri yapılmıştır. Daha sonra tüm verim döneminin ortası olan 52. hafta ile son dönemi 70. haftada yumurta kalite analizleri yeniden ölçülmüştür. Kümes içerisinde 5 blok halinde bulunan kafeslerde orta bloğun 1, 3 ve 5 katlarından alınan yumurtalar kalite analizinde kullanılmıştır. Her katın sağ tarafından 30 adet olmak üzere toplam 90 adet yumurta viyollere alınarak 1 gün (24 saat) oda sıcaklığında ölçüm ve tahlilleri yapılmak üzere bekletilmiştir. Ertesi gün yumurtalar numaralandırılarak dış kalitesini belirlemek için Niğde Üniversitesi Tarım Teknolojisi Fakültesi hayvansal üretim laboratuvarına götürülerek belirlenen metotlarla analiz edilmiştir.

\section{Yöntem}

Yumurta dış kalitesinin belirlenmesinde aşağıdaki yöntemler kullanılmıştır.

\section{Yumurta kabuk kalınlığı (mm)}

Türkoğlu ve Sarıca,( 2009)'ya göre, Yumurta kabuklarının $0.001 \mathrm{~mm}$ hassasiyetindeki dijital mikromet- re ile küt, sivri ve orta kısımlarından yapılan ölçümlerinin ortalaması alınarak hesap edilmiștir.

\section{Kabuk kırılma direnci (Kg)}

Yumurta kabuğu kırılma direnci Egg Force Reader (06-UM-001, Version B, Orka Food Tech. Ltd., Hong Kong, China) cihazı ile tespit edilmiștir (Sert ve ark., 2011; Aygun ve Sert, 2013).

\section{Yumurta kabuğu yüzey alanı (A)}

Așağıdaki formül yardımıyla hesaplanmıştır (Nordstorm ve Ousterhout, 1982).

\section{$A=3,9782 \times$ Yumurta a ğırlı̆̆ 0,7056}

İstatistiki Analizler: Veriler SPSS 17,0 istatistik paket programında, 3 faktörlü ve faktörlerin birinin seviyeleri tekrarlanan ölçüm içeren deneme tertibine göre yürütülmüştür (Bek ve Efe, 1999).

\section{Bulgular ve Tartışma}

\section{Yumurta dış kalite özellikleri}

Yumurta dış kalite özeliklerinden 6 parametre çalışılmıştır. Bunlar sırası ile yumurta ağırlığı (g), şekil indeksi (\%), özgül ağırlığı $\left(\mathrm{g} / \mathrm{cm}^{3}\right)$, kabuk kalınlığı $(\mu)$, kabuk kırılma direnci $\left(\mathrm{kg} / \mathrm{cm}^{2}\right)$, yumurta kabuğu yüzey alanı $\left(\mathrm{cm}^{2}\right)$ dir. Yumurtacı tavuklarda genotip, kafes katı ve yaşın yumurta dış kalite özelliklerine etkileri ayrı ayrı değerlendirilmiştir. Ayrıca yumurta dış kalitesine genotip*kat, genotip*yaş, yaş*kat, genotip*kat*yaş interaksiyonlarının etkileri araştırılmıştır. Elde edilen veriler Çizelge 3'de gösterilmiştir.

\section{Yumurta dış kalite özelliklerine genotip'in etkisi}

Beyaz ve kahverengi yumurtacılarda, yumurta ağırlığ 67,009-68,921 (g), şekil indeksi \% 74,657-78,500, özgül ağırlığı 1,094-1,099 (g/ $\left.\mathrm{cm}^{3}\right)$, kabuk kalınlığı 388,20-391,27 $(\mu)$, kabuk kırılma direnci 4,5274,516 (kgf), yumurta kabuğu yüzey alanı 77,24178789 (A) olarak ölçülmüştür. Yumurtacı tavuklarda genotipin dış kalite özelliklerine etkileri incelendiğinde yumurta ağırlı̆̆ı (g), şekil indeksi (\%), kabuk kalınlığı $(\mu)$, yumurta kabuğu yüzey alanına etkileri istatistiki olarak önemli bulunmuştur $(\mathrm{P}<0.01)$. Genotipin diğer dış kalite özelliklerine etkilerine bakıldığında özgül ağırlı̆̆ $\left(\mathrm{g} / \mathrm{cm}^{3}\right)$ ve kabuk kırılma direnci (kgf), etkileri önemsiz bulunmuştur. $(\mathrm{P}<0.01)$. Yumurta dış kalite özelliklerine genotipin etkileri bakımından, Alkan ve Ark.(2010) 11 generasyon boyunca seleksiyona tabi tutulmuş, japon bıldırcınlarında, seleksiyonun genotiplerde yumurta ağırlığl, yumurta kabuk kalınlı̆̆ı, Şekil indeksi parametreleri bakımından ağır ırkların orta ve hafif ırklara göre farklılığın önemsiz olduğunu bildirdikleri çalışma ile uyumsuzdur. 
Araștırma sonuçları Durmuș (2006) ve Khan'ın (2004) ile Sarıca ve ark.(2010), Sarıca ve ark.'nın (2012), Singh ve ark. (2009), Zita ve ark. (2008) tavuklarda genotipin yumurta kalitesine etkilerinin önemli olduğunu bildirdikleri çalıșmalarla uyum içerisindedir. Aynı şekilde Tümova ve ark. (2007) genotipin yumurta ağırlığı ve yumurta kabuk kalınlı- ğına etkileri bakımından bulunan farklılıklar önemli bulurken $(\mathrm{P}<0.01)$, yumurta kabuk direnci ile Şekil indeksi bakımından farklılıkların önemsiz olduğunu bildirmişlerdir. Mevcut sonuçlar karşılaştırıldığında genotipin yumurta ağırlığı ve yumurta kabuk direnci açısında uyumlu ancak yumurta kabuk kalınlığı ile Şekil indeksi yönünden uyumsuzdur.

Çizelge 3. Yumurtacı tavuklarda genotip, kafes katı ve yaşın yumurta dış kalite özelliklerine etkileri ( \pm SH)

\begin{tabular}{|c|c|c|c|c|c|c|c|}
\hline Özellik & Gruplar & $\begin{array}{c}\text { Yumurta Ağırlı- } \\
\text { ğl (g) }\end{array}$ & $\begin{array}{l}\text { Şekil İndeksi } \\
(\%)\end{array}$ & $\begin{array}{l}\text { Özgül ağırlık } \\
\left(\mathrm{gr} / \mathrm{cm}^{3}\right)\end{array}$ & $\begin{array}{l}\text { Kabuk kalınlığ } \\
(\mu)\end{array}$ & $\begin{array}{l}\text { Kırılma direnci } \\
\text { (kgf) }\end{array}$ & Yüzey alanı $\left(\mathrm{cm}^{2}\right)$ \\
\hline \multirow{2}{*}{ Genotip } & Beyaz & $67.009 \pm 0.324$ & $74.657 \pm 0.191$ & $1.094 \pm 0.002$ & $388.2 \pm 0.148$ & $4.527 \pm 0.04$ & $77.24 \pm 0.26$ \\
\hline & Kahve & $68.921 \pm 0.324$ & $78.500 \pm 0.191$ & $1.099 \pm 0.002$ & $391.2 \pm 0.148$ & $4.516 \pm 0.045$ & $78.78 \pm 0.261$ \\
\hline \multirow{3}{*}{ Kat } & Kat 1 & $68.778^{a} \pm 0.397$ & $76.803 \pm 0.234$ & $1.095 \pm 0.003$ & $393.9^{\mathrm{a}} \pm 0.181$ & $4.544^{\mathrm{a}} \pm 0.055$ & $78.68^{a} \pm 0.32$ \\
\hline & Kat 3 & $66.863^{\mathrm{b}} \pm 0.397$ & $76.638 \pm 0.234$ & $1.096 \pm 0.003$ & $393.7^{\mathrm{a}} \pm 0.181$ & $4.693^{\mathrm{a}} \pm 0.055$ & $77.11^{b} \pm 0.32$ \\
\hline & Kat 5 & $68.255^{\mathrm{ab}} \pm 0.397$ & $76.294 \pm 0.234$ & $1.100 \pm 0.003$ & $381.5^{\mathrm{b}} \pm 0.181$ & $4.327^{b} \pm 0.055$ & $78.24^{\mathrm{ab}} \pm 0.32$ \\
\hline \multirow{3}{*}{ Yaş } & $28 \mathrm{hf}$ & $63.637^{b} \pm 0.365$ & $77.271^{\mathrm{a}} \pm 0.224$ & $1.097 \pm 0 ?$ & $390.3 \pm 0.143$ & $4.774^{\mathrm{a}} \pm 0.051$ & $74.491^{b} \pm 0.3$ \\
\hline & $52 \mathrm{hf}$ & $69.850^{a} \pm 0.363$ & $75.840^{\mathrm{b}} \pm 0.272$ & $1.090 \pm 0 ?$ & $392.3 \pm 0.196$ & $4.238^{c} \pm 0.063$ & $79.56^{\mathrm{a}} \pm 0.291$ \\
\hline & $70 \mathrm{hf}$ & $70.409^{a} \pm 0.378$ & $76.623^{\mathrm{ab}} \pm 0.194$ & $1.103 \pm 0.005$ & $386.5 \pm 0.198$ & $4.551^{\mathrm{b}} \pm 0.059$ & $79.995^{\mathrm{a}} \pm 0.302$ \\
\hline \multicolumn{2}{|c|}{$P_{\text {genotip }}$} & $* *$ & $* *$ & ÖNSZ & $* *$ & ÖNSZ & $* *$ \\
\hline \multicolumn{2}{|c|}{$P_{\text {kat }}$} & $* *$ & ÖNSZ & ÖNSZ & $* *$ & $* *$ & $* *$ \\
\hline \multicolumn{2}{|c|}{$P_{\text {yaş }}$} & $* *$ & $* *$ & ÖNSZ & ÖNSZ & $* *$ & $* *$ \\
\hline \multicolumn{2}{|c|}{$\mathrm{P}_{\text {genotip*kat }}$} & $* *$ & $* *$ & ÖNSZ & $* *$ & $* *$ & $* *$ \\
\hline \multicolumn{2}{|c|}{$P_{\text {genotip*yaş }}$} & $* *$ & $* *$ & $* *$ & $* *$ & $* *$ & $* *$ \\
\hline \multicolumn{2}{|c|}{$\mathrm{P}_{\text {yaş*kat }}$} & $* *$ & $* *$ & $* *$ & $* *$ & $* *$ & $* *$ \\
\hline \multicolumn{2}{|c|}{ Pgenotip*kat*yaș } & $* *$ & $* *$ & $* *$ & $* *$ & $* *$ & $* *$ \\
\hline
\end{tabular}

* Aynı sütunda farklı harfi üs olarak taşıyan grup ortalamaları arasındaki farklılıklar önemlidir $(\mathrm{P}<0,05)$.

** Aynı sütunda farklı harfi üs olarak taşıyan grup ortalamaları arasındaki farklılıklar önemlidir $(\mathrm{P}<0,01)$.

ÖNSZ Aynı sütunda ÖNSZ ile gösterilen grup ortalamaları arasındaki farklılıklar önemsizdir $(\mathrm{P}<0,05)$.

\section{Yumurta dış kalite özelliklerine kafes katının etkisi}

Kafes katlarının $(1,3,5)$ yumurtaların dış kalite özelliklerine etkisinin belirlenmesi için yapılan araştırmada; belirlenen kafes katlardaki elde edilen yumurtaların dış kalite özellikleri sırasıyla yumurta ağırlıkları sırsıyla 68,778-66,863-68,255(g), Şekilşekil indeksleri \%76,803-76,638-76,294, özgül ağırlıkları 1,095-1,096-1100 (g/ $\left.\mathrm{cm}^{3}\right)$, kabuk kalınlıkları 393,91-393,74-381,55 ( $\mu$ ), kabuk kırılma dirençleri 4,544-4,693-4,327 (kgf), yumurta kabuğu yüzey alanları 78,683-77,119-78,244 (cm²) olarak ölçülmüştür. Yumurtacı tavuklarda kafes katının dıș kalite özelliklerine etkileri incelendiğinde yumurta ağırlığı (g), kabuk kalınlığı (mm), kabuk kırılma direnci $\left(\mathrm{kg} / \mathrm{cm}^{2}\right)$, yumurta kabuğu yüzey alanına etkileri istatistiki olarak önemli bulunmuştur. $(\mathrm{P}<0.01)$. Kafes katlarının diğer dıș kalite özelliklerine etkilerine bakıldığında Şekil indeksi (\%), özgül ağırlığı $\left(\mathrm{g} / \mathrm{cm}^{3}\right)$, etkileri önemsiz bulunmuştur $(\mathrm{P}>0.01)$. $\mathrm{Bu}$ sonuç Ylldırım ve ark., (2008) kafes katlarının yumurta şekil indeksine etkisinin önemsiz bulunduğu çalışmayla uyumlu olduğu görülmüştür. Yumurta dış kalite özelliklerine kafes katının etkileri Çizelge 3'te gösterilmiştir. Konuyla ilgili yürütülen çalışmalarda; Yıldız ve ark. (2006) Kafes katının yumurta ağırlığı, kabuk kalınlığı, kabuk kırılma dirençleri arasındaki farklılıkların önemli olduğunu $(\mathrm{P}<0.01)$ kafes katının şekil indeksine etkisinin ise önemsiz olduğunu bildirmişlerdir. İlgili çalışma ile mevcut araştırma sonuçları uyumludur. Onbaşılar ve ark.(2005) yumurta tavuklarında farklı kafes katlarının yumurta kalitesi özelliklerinin etkilerinin araştırıldığı çalışmada: farklı kafes katından elde edilen yumurtaların ağırlığı ve kabuk kalınlığındaki farklılıkları önemli bulduklarını bildirmişlerdir $(\mathrm{P}<0.01)$. İlgili çalışma ile araştırma sonuçları uyumludur. Şekeroğlu ve ark. (2014) yumurta tavuklarının farklı yerleşim sistemlerinin yumurta kalite- 
sinin etkilerinin araştırıldığı çalışmada; kafes katından kaynaklanan şekil indeksi, özgül ağırlık, kabuk kalınlığı ve kabuk kırılma direncindeki farklılıklar önemsiz olduğunu bildirmişlerdir ( $\mathrm{P}>0.05)$. İlgili çalışma ile mevcut araştırma sonuçları ile şekil indeksi ve özgül ağırlık bakımından uyumlu fakat kabuk kalınlığı ve kabuk kırılma direncindeki farklılıklar bakımından uyumsuzdur. Karaman ve ark. (2013) Yumurta tavuklarında farklı kafes katlarının yumurta kalitesine etkilerinin araştırıldığı çalışmada: kafes katının özgül ağırlık, şekil indeksi, kabuk kalınlığı, kabuk kırılma direnci, kabuk yüzey alanına etkisi önemsiz bulduklarını bildirilmişlerdir $(\mathrm{P}<0.05)$. Mevcut çalışma ile özgül ağırlık, şekil indeksinde araştırma sonuçları uyumlu, kafes katının kabuk kalınlığı, kabuk kırılma direnci, kabuk yüzey alanına etkileri bakımından uyumsuzdur. Kılıç ve ark. (2006) Yumurta tavuklarında farklı kafes katlarının yumurta kalitesi özelliklerinin etkilerinin araştırıldığı çalışmada: farklı kafes katından elde edilen yumurtaların ağırlığı, şekil indeksi ve kabuk kalınlığındaki farklılıkların önemsiz olduğunu bildirmişler$\operatorname{dir}(\mathrm{P}>0.05)$. Bu çalışmanın sonuçları ile şekil indeksi bakımından uyumlu fakat kabuk kalınlığı, yumurta ağırlığı arasındaki farklılıklar bakımından benzerlik bulunamamıştır.

\section{Yumurta dış kalite özelliklerine yaşın etkisi}

Beyaz ve kahverengi yumurtacılarda farklı yaş döneminde (28, 52, 70. hafta) elde edilen yumurtaların bazı dış kalite parametreleri (yumurta ağırlığı, şekil indeksi, özgül ağırlığı, kabuk kalınlığı, kabuk kırılma direnci, yumurta kabuğu yüzey alanı) incelenmiştir. Yaş grupları bakımından bunlar sırası ile yumurta ağırlığı 63,637-69,850-70,409(g), şekil indeksi \%77,271-75,840-76,623, özgül ağırlığ 1,097-1,0901,103 (g/ $\left.\mathrm{cm}^{3}\right)$, kabuk kalınlı̆̆ $390,31-392,35-$ 386,54 ( $\mu$ ), kabuk kırılma direnci 4,774-4,238-4,551 (kgf), yumurta kabuğu yüzey alanı 74,491-79,560$79,995\left(\mathrm{~cm}^{2}\right)$ olarak tespit edilmiştir. Buna göre; yaşın yumurta ağırlığı, şekil indeksi, kırılma direnci ve kabuk yüzey alanına etkilerine göre farklılıklar istatistiki olarak önemli bulunmuştur $(\mathrm{P}<0.01)$. Yaşın özgül ağırlık ve kabuk kalınlığına etkilerine göre farklılıklar önemsizdir ( $\mathrm{P}>0.05)$. Altan ve ark. (1996), Japon Bıldırcınlarında yürüttükleri çalışmada; yumurta ağırlığı ve Şekil indeksi sonuçları ile mevcut sonuçlar uyumlu ancak yaşın yumurta kabuğu kalınlığına etkisi bakımından uyumsuzdur. Brand ve ark. (2004) yumurta tavuklarında yaşın yumurta kalitesine etkilerinin araştırıldı̆̆ı çalışmada; tavuk yaşının yumurta ağırlığı, Şekil indeksine etkisinin önemli $(\mathrm{P}<0,01)$, ancak kabuk kalınlığının önemsiz bulunduğunu bildirilmişlerdir. Bu çalışma ile araştırma sonuçlarımız uyum içerisindedir. Onbaşılar ve ark.(2005) Yumurta tavuklarında farklı yaş dönemlerinin yumurta kalitesi özelliklerinin etkilerinin araştırıldığı çalışmada: farklı yaş dönemlerinde elde edilen yumurtaların ağırlık, kabuk kırılma direnci ve kabuk kalınlığındaki farklılıkların önemli olduğunu bildirmişlerdir. İlgili çalışmadaki yumurta ağırlığı ve kırılma direncine göre bulunan sonuçlar ile bu araştırmanın sonuçları uyumlu fakat yaşın yumurta kabuğu kalınlığına etkisi bakımından uyumsuzdur. Petek ve ark. (2009) değişik yaşlardaki yumurta tavuklarının yumurta kalitesine etkilerinin araştırıldığı çalışmada; tavuk yaşının yumurta ağırlığı, özgül ağırlık, kabuk kalınlığı ve kabuk kırılma direncine etkisi bakımından farklılıklar önemli bulunurken $(\mathrm{P}<0.01)$, şekil indeksine etkisi önemsiz bulunmuştur. İlgili çalışmadaki yumurta ağırlığı ve kırılma direncine göre bulunan sonuçlar ile mevcut araştırma sonuçları uyumlu ancak özgül ağırlık ve yumurta kabuğu kalınlığı bakımından uyumsuzdur. Sarıca ve ark. (2010), dış kaynaklı ve yerli yumurtacı hibritlerde yumurta kalitesinin yaşa bağlı değişimi konusunda yapılan çalışmada yaşın yumurta ağırlığı, kabuk kalınlığı, Şekil indeksi, özgül ağırlığı, kabuk klrılma direncine etkisine göre oluşan farklılıkların önemli olduğu bildirilmiştir $(\mathrm{P}<0,01)$. İlgili çalışmadaki yumurta ağırlığı, Şekil indeksi, kabuk kırılma direnci bakımından mevcut araştırma sonuçları uyumlu ancak yaşın özgül ağırlık ve yumurta kabuğu kalınlı̆̆ bakımından uyumsuzdur. Şekeroğlu ve ark.(2014) yumurta tavuklarında farklı yaş evrelerinin yumurta kalitesi üzerine etkilerinin araştırıldığı çalışmada; yumurta ağırlığı, özgül ağırlık, kabuk kalınlığı ve kabuk kırılma direncindeki farklılıklar önemli bulurken $(\mathrm{P}<0.01-\mathrm{P}<0.05)$, Şekil indeksine etkisi önemsiz bulunmuştur. İlgili çalışmasındaki yumurta ağırlığı, kabuk kırılma direnci sonuçları ile mevcut araştırma sonuçları ile uyumlu fakat kabuk kalınlığı, özgül ağırlık ve Şekil indeksi bakımından uyumsuzdur. Singh ve ark. (2009), 4 ayrı genotipin, kafes ve yer sisteminde 20,30, 40 ve 50 haftalık yaşların yumurta ağırlığı göre bulunan farklılıklar önemli bulunmuştur. $(\mathrm{P}<0,05)$. İlgili çalışma ile mevcut araştırma sonuçları uyumludur. Zita ve ark. (2009), yumurta tavuklarında farklı genotiplerin ve yaşların yumurta kalite üzerine etkisinin tespiti amacıyla yapılan araştırmada, yaşın yumurta ağırlığı, Şekil indeksine etkileri bakımından farklılıklar önemli bulunmuştur $(\mathrm{P}<0.01)$. İlgili çalışma ile mevcut araştırma sonuçları uyumludur. 


\section{Yumurta dış kalite özelliklerine interaksiyonla- rin etkisi}

Çalışmada beyaz ve kahverengi yumurtacılardan genotip*kat intraksiyonunun yumurta ağırlığı, Şekil indeksi, kabuk kalınlığı, kırılma direnci ve yumurta kabuk alanına etkileri bakımından farklılıklar önemlidir $(\mathrm{P}<0.01)$. Genotip*kat intraksiyonunun yumurta özgül ağırlığında etkisinin önemsizdir $(\mathrm{P}<0.05)$. Genotip*yaş İntraksiyonunun yumurta ağırlığı, Şekil indeksi, özgül ağırlık kabuk kalınlığı, kırılma direnci ve yumurta kabuk alanına etkisi bakımından farklılıklar önemlidir $(\mathrm{P}<0.01)$. Yaş*kat intraksiyonunun yumurta ağırlığı, Şekil indeksi, özgül ağırlık kabuk kalınlığı, kırılma direnci ve yumurta kabuk alanına etkileri önemlidir $(\mathrm{P}<0.01)$. Genotip*yaş*kat interaksiyonunun yumurta ağırlığı, Şekil indeksi, özgül ağırlık kabuk kalınlığı, kırılma direnci ve yumurta kabuk alanına etkisi bakımından farklılıklar önemlidir $(\mathrm{P}<0.01)$. Zita ve ark. (2009), Yumurta tavuklarında genotip*yaş interaksiyonunun yumurta kalite üzerine etkisinin tespiti amacıyla yaptıkları araştırmada yumurta ağırlı̆̆l, şekil indeksi, yönünden değişik yaşlarda farklılıkların önemli olduğunu bildirmişler$\operatorname{dir}(\mathrm{P}<0.01)$. İlgili çalışma ile araştırma sonuçları uyumludur. .Karaman ve ark.(2013) Yumurta tavuklarında değişik kafes katlarının yumurta kalitesi özelliklerinin etkilerinin araştırıldığı çalışmada: yaş*kat interaksiyonunun kabuk kalınlığı, kırılma direncine etkileri bakımından görülen farklılıkların önemli $(\mathrm{P}<0.01)$, yumurta ağırlı̆̆, Şekil indeksi, özgül ağırlık ve yumurta kabuk alanına etkileri önemsiz olduğunu bildirilmişlerdir. İlgili çalışmadaki sonuçlarda yaş*kat interaksiyonunun kabuk kalınlı$\breve{g}$, kırılma direncine etkilerine göre bulunan sonuçlar ile mevcut araştırma sonuçları uyumlu ancak yumurta ağırlığı, Şekil indeksi, özgül ağırlık ve yumurta kabuk alanına etkileri bakımından uyumsuzdur. Kılıç ve ark.(2006) Yumurta tavuklarında değişik yaş dönemlerinin yumurta kalitesine etkilerinin araştırıldığ $\breve{I}_{1}$ çalışmada; yaş*kat interaksiyonunun yumurta ağırlığı, şekil indeksi ve kabuk kalınlığına göre farklllıkların önemsiz olduğunu bildirilmiştir. İlgili çalışma ile mevcut araştırma sonuçları uyumsuzdur. Onbaşılar ve ark.(2005) Değişik yaşlardaki yumurta tavuklarında farklı kafes katlarının yumurta kalitesi özelliklerinin etkilerinin araştırıldığı çalışmada: yaş*kat interaksiyonunun kabuk kalınlığındaki farklılıklar önemsiz olduğunu bildirmişlerdir. İlgili çalışma ile mevcut araştırma sonuçları uyumsuzdur. Singh ve ark. (2009), 4 ayrı genotipte kafes ve yer sisteminde $20,30,40$ ve 50 haftalık yaşların yumurta kalitesine etkilerinin araştırıldığı çalışmada; yaş*kat, genotip*yaş, kat*yaş*genotip intraksiyonunun yumurta ağırlığına etkileri yönünden görülen farklılıklar önemli bulunmuştur. $(\mathrm{P}>0,01)$ İlgili çalışma ile araştırma sonuçları uyumludur.

\section{Sonuçlar ve Öneriler}

$\mathrm{Bu}$ araștırmada ticari beyaz ve kahverengi yumurtaclların yumurta kalite özellikleri bakımından genotip, kat, yaş, göre farklılıkları ortaya konulmuştur. Çalışma sonuçlarına göre;

A-Genotip: Kahverengi yumurtaciların elde edilen yumurtalar yumurta ağırlığı, özgül ağırlık, Şekil indeksi, kabuk kalınlığı, yumurta kabuğu yüzey alanı, değerleri bakımından beyazlara gore yüksek bulunmuştur. Kafes katları ile ilgili elde edilen sonuçlar; Birinci kafes katının yumurta ağırlığı, Şekil indeksi, kabuk kalınlığı, kabuk yüzey alanı, diğer katlara (3-5) göre daha yüksek bulunmuştur. En yüksek kabuk kırılma direnci 3. kafes katında bulunmuştur. Beşinci Kafes katının yumurtalarının, 1. ve 3. kafes katına gore kabuk kalınlığının daha ince, dolayısıyla kabuk kırılma direncinin ise daha düşük olduğu görülmüştür. Yaş ile ilgili elde edilen sonuçlar; Yumurta tavuklarında yaş ilerledikçe yumurta ağırlığının ve özgül ağırlı̆̆ı arttığı, buna karşın kabuk kalınlığı değerinin düştüğü görülmektedir.

B- İntraksiyonlar: Genotip, yaş ve kat intraksiyonlarında farlılıkların önemi artmıştır. En yüksek yumurta ağırlığı kahverengi yumurtacılarda 3. kafes katında 70. haftada elde edilmiştir. En düşük yumurta ağırlığı; kahverengi yumurtacılarda 5. kafes katında 28. haftada, beyaz yumurtacilarda 3 . ve 5 . kafes katında 28. haftada elde edilen yumurtalarda görülmüştür. 28. Haftalık yumurtacı tavuklarda 1. Kafes katında Şekil indeksinin en yüksek, 5. kafes katında 52. haftalık yaşta elde edilen yumurtaların Şekil indekslerinin en düşük olduğu görülmektedir. En yüksek özgül ağırlık kahverengi yumurtacılarda 5 kafes katında 70. haftada elde edilmiştir. En düşük özgül ağırlık; beyaz yumurtacılarda 1. kafes katında 52. hafta da, elde edilen yumurtalarda bulunmuştur. En yüksek yumurta kabuk kalınlı̆̆l, kahverengi yumurtacılarda 3. kafes katında, 28. hafta da elde edilmiştir. En düşük yumurta kabuk kalınlığl; beyaz yumurtacılarda 3 . kafes katında 70 . haftada, elde edilen yumurtalarda bulunmuştur. En yüksek kabuk kırılma direnci 3. Kafes katında 28. haftalık yaşta bulunmuştur. 
En düșük kabuk kırılma direnci 5. Kafes katında 52. haftalık yaşta bulunmuştur. En yüksek yumurta kabuğu yüzey alanı kahverengi yumurtacılarda 3. kafes katında 70. haftada elde edilmiștir. En düșük yumurta kabuğu yüzey alanı beyaz yumurtacılarda 3 . kafes katında 28. haftada elde edilen yumurtalarda görülmüştür. Genel olarak ticari beyaz ve kahverengi yumurtacıların yumurta kalite özellikleri bakımından bulunan farklılıklar değerlendirildiğinde; genotip, yaş ve kafes katının yumurta ağırlı̆̆ı, özgül ağırlık ve kabuk özelliklerine önemli etkileri bulunmuștur $(\mathrm{P}<0,01)$. Kahverengi yumurtaların beyaz yumurtalara göre daha ağır ve özgül ağırlıklarının daha fazla oldukları tespit edilmiştir. Kafes katlarının yumurta kalitesine etkileri incelendiğinde, birinci katın yumurta ağırlığı, Şekil indeksi, kabuk kalınlığı, kabuk yüzey alanı parametreleri bakımından diğer katlara (3-5) göre daha yüksek bulunmuştur $(\mathrm{P}<0,01)$. Ticari yumurta tavukçuluğunda, yumurta üretimi yanında yumurta kalitesi ile ilişkili konularda beyaz veya kahverengi hibritlerin genetik potansiyellerinin belirlenmesi önemlidir. Kahverengi yumurtaclar ile beyaz yumurtacıların diş yumurta kaliteleri birbirinden bazı farlılıkları olduğu yapılan araştırmada ortaya konmuștur. Bu farklılıklar kimi zaman üretim ve pazarlama aşamalarında avantaj ve dezavantaj şeklinde üretimi ve tüketimi etkilemektedir. Ülkemizde yumurta ağırlığını ve büyüklüğünü önemseyen tüketici alıșkanlıkları olduğu bilinen bir gerçektir. Bu araştırma sonuçlarına göre kahverengi yumurta tercihi tüketici bazında önemsenmektedir. Modern yumurta tavukçuluğunda yer sistemlerinden daha çok kafes sistemi tercih edilmektedir.

Kafes sisteminde kafes katlarının sayısı ve yüksekliği yönüyle hem de yumurta kalitesi, pazar paylarının belirlenmesi açılarından araştırma sonuçları değerlendirilmelidir. Buna göre yere yakın yani 1 . kafes katında yetiştirilen yumurta tavuklarının yumurtaları daha ağır ve kalın kabuklu olması sebepleri ile tercih konusu olabilir. Çünkü Kalın kabuklu ve ağır yumurtalar albeni, hijyen, saklama koşulları, kullanışlı olması tüketicilerin öncelikli tercih sebebidir. Kafes katları açısından yumurta kalitesinde görülen farklılıkların muhtemel sebepleri arasında kafes katlarının hem sıcaklık hem de ışık şiddeti yönüyle oldukça farklılık göstermesidir. Bu nedenle kafeste katlar arası oluşan farklılıkların ortadan kaldırılması için araștırmamızda ölçtüğümüz sıcaklık ve ıșik yoğunluğu farklılıkları elemine edilerek üniform yumurta üretimi için şartlar oluşturulmalıdır.

\section{Kaynaklar}

Alkan S., Karadağ K., Galiç A., Karslı T., Balcıoğlu M.S., 2010 Effects of Selection for Body Weight and Egg Production on Egg Quality Traits in Japanese Quails (Coturnix coturnix japonica) of Different Lines and Relationships between These Traits. Kafkas Univ Vet Fak Dergisi 16 (2), 277-280.

Altan Ö., Oğuz i., Settar P., 1995 "Japon bıldırcınlarında yumurta ağırlığı ile özgül ağırlığının kuluçka özelliklerine etkileri." Tr. J. Agric. Forest 19 (1995): 219-222.

Aygun, A. and Sert, D., 2013, Effects of vacuum packing on eggshell microbial activity and egg quality in table eggs under different storage temperatures, Journal of the Science of Food and Agriculture, 93 (7), 1626-1632.

Bek, Y. ve Efe, E., 1995 Araştırma Deneme Metodları I. Ç. Ü. Z. F. Ders Kitabı, 395s. Yayın No:71, Adana.

Brah G.S. and Chaudhary M.L., 1998 Inheritance of shell quality related egg traits. Indian Journal of Poultry Sci, 33(3), 309-316.

Van Den Brand H., 2004 Effects of housing system (outdoor vs cages) and age of laying hens on egg characteristics Journal home page: http://www. tandfonline .com/ loi/cbps20, (December 2004) British Poultry Science, 45:6, 745

Durmuş İ., 2006 Geliștirilmekte olan yerli beyaz yumurtacı saf hatlar ve hibritlerinde verim özellikleri, yumurta kalitesi ve kuluçka sonuçlarının belirlenmesi Mart 2006 Ankara, 43-52.

Jacob Jacqueline P., Richard D., Miles and F. Ben Mather 1998, Egg Quality. University Of Florida Cooperative Extension Service Institute Of Food And Agricultural Sciences, Fact Sheet. ps.24.

Karaman S., A Sekeroglu A., Duman M., 2013 Physical characteristics and performance of laying hens caged in different tiers and environmental parameters of each tier transactions of the ASABE American Society of Agricultural and Biological Engineers, Tokat $326 \mathrm{~s}$.

Khan MKI., Khatun MJ., Kibria A., 2004, Study the Quality of Eggs of Different Genotypes of Chickens under Semi-scavenging System at Bangladesh Institute of Veterinary, Animal and Biomedical Science, Massey University, PalmerstonNorth-11 222, 2004NewZealand, 2165

Kılıç İ., ve Şimşek E., 2006, Bursa Bölgesinde Bir Yumurta Tavuğu Kümesinin Yapı İçi İklimsel Çevre Koşullarının Yumurta İç ve Dış Kalite Özellikleri Üzerine Etkilerinin Belirlenmesi U.Ü. Ziraat Fakültesi Dergisi Sayı: 2, 21 Bursa 34-37 
Laxmi PJ., Prasad VLK., 2001 Inheritance of various egg quality traits in three strains of white leghorns. Indian Veterinary Journal, 78 (9)., 820-823.

Laxmi PJ., Prasad VLK., Murthy ASR., 2002, Inheritance of various egg quality traits in three strains of white leghorns. Indian Veterinary Journal, 78 (9)., 820823.

Onbaşlar EE., Aksoy FT., 2005, Stress parameters and immune response of layers under different cage floor and density conditions Ankara University, Faculty ofVeterinary Medicine, Department of Animal Science, January 2005, Ankara 258-259

Pavlovski Z., Hopic S., Lukic M 2001, "Housing systems for layers and egg quality." Biotehnologija u stocarstvu (Yugoslavia) (2001).

Petek M., Alpay F., Gezen ŞŞ., Çıbık R., 2009, Effects of Housing System and Age on Early Stage Egg Production and Quality in Commercial Laying Hens Kafkas Üniv Vet Fak Derg. -15 (2009) Bursa 57-62

Sarıca M., Yamak US., Boz MA., 2010 Dış Kaynaklı ve Yerli Yumurtacı Hibritlerde Yumurta Kalitesinin Yaşa Bağlı Değişimi Tavukçuluk Araştırma Dergisi 1117, 2010 Ankara Tavukçuluk Araştırma İst 13-16

Sarıca M., Onder H., Yamak US., 2012, Determining the Most Effective Variables for Egg Quality Traits of Five Hen Genotypes international Journal Of Agriculture \& Biology, 14(2): 235-240.

Sert, D., Aygun, A., Demir, M. K., 2011, Effects of ultrasonic treatment and storage temperature on egg quality, Poultry science, 90 (4), 869-875.

Siegel P.B., Lamont S., Pinard-van der Laan 2004, Quantitative genetics and egg quality. XXII. Worlds Poultry Congress. June 8-13.,129, İstanbul.

Singh R., Cheng KM., Silversides FG., 2009, Production performance and egg quality of four strains of laying hens kept in conventional cages and floor pens Department of Animal Science, Canada2009 Poultry Science 88: 256-264

Şekeroğlu A., Duman M., Tahtalı Y., Yıldırım A., 2014, Effect of cage tier and age on performance, egg qua- lity and stress parameters of laying hens URL: http://www.sasas.co.za ISSN 0375-1589 (print), ISSN 2221-4062 (online) Publisher: South African Society for Animal Sci 44

Şekeroğlu A. ve Özen N., 1997, "Gerze (Hacıkadı) ve Denizli tavuk ırklarının bazı verim özellikleri bakımından karşılaştırılması." Akdeniz Üniv Ziraat Fak Derg 10 41-57.

Şekeroğlu A., Dülger H., Arik M., 2002, Pro-inflammatory cytokines in Turkish children with protein-energy malnutrition. Mediators of inflammation, 11(6), 363-365.

Türkiye İstatistik Kurumu (TÜIK), 2016. https://biruni.tuik.gov.tr/medas/?kn=80\&locale=t r (Erişim Tarihi 10.12.2018)

Tümova E., Zita L, Hubený M., Skřivan M., 2007 The effect of oviposition time and genotype on egg quality characteristics in egg type hens Supported by the Ministry of Education, Youth and Sports of the Czech Republic (Project No. MSM 6046070901) and Ministry of Agriculture of the Czech Republic Czech J. Anim. Sci., 52, (1): 26-30.

Türkoğlu M., ve Sarıca M., 2009, "Tavukçuluk Bilimi (Yetiştirme ve Besleme Hastalıkları)." Bey ofset Matbaacllık Ankara (2009) 3. Basım, s., 588.

Yıldırım, İ., Parlat, S. S., Aygün, A. ve Yetişir, R., 2008, Apartman Tipi Kafeste Uygulanan Askılı Aydınlatma Sisteminin Kahverengi Yumurtacı Hibritlerin Performans, Yumurta Kalite Özellikleri ve Stres Düzeyine Etkileri, Selçuk Tarım ve Gıda Bilimleri Dergisi, 22 (44), 7-11

Yıldız A., Lacin E., Hayirli A., 2006, Effects of Cage Location and Tier Level with Respect to Light Intensity in Semiconfined Housing on Egg Production and Quality During the Late Laying Period (C)2006 Poultry Science Association, Inc 2006 J. Appl. Poult. Res. 15:355-361.

Zita L., Tůmová E., Štolc L., 2009 Effects of Genotype, Age and Their Interaction on Egg Quality in Brown-Egg Laying Hens Department of Animal Husbandry, Faculty of Agrobilology. 